\title{
MINERALOGICAL STUDY OF INORGANIC INTERCALATED SEAMS AT ACHLADA LIGNITE DEPOSITS (NW GREECE)
}

\author{
Oikonomopoulos I. ${ }^{1}$, Perraki Th. ${ }^{1}$, Kaouras G. ${ }^{1}$, and Antoniadis P. ${ }^{1}$ \\ ${ }^{1}$ National Technical University of Athens, Faculty of Mining Engineering, Department of \\ Geological Sciences, giannis@metal.ntua.gr,perraki@metal.ntua.gr,antoniad@metal.ntua.gr
}

\begin{abstract}
We study the inorganic intercalated horizons of "Achlada" lignite deposits in Florina basin combining the mineralogical study and initial palaleobotanical data. The samples were investigated by means of X-ray diffraction (XRD), thermogravimetric (TG/DTG) and differential thermal analysis (DTA) and Fourier Transform (FT-IR) spectroscopy. The clay minerals prevail in all samples, with illite being the dominant phase, kaolinite and chlorite to be the next. No smectite was found. In addition to clay minerals, the other mineral phases identified are mainly quartz and feldspars. The presence of siderite, in the majority of the samples, is also remarkable. The illite, kaolinite and chlorite percentages of the thicker inorganic horizon were correlated to the paleoenvironmental data. The classification of this particular material into appropriate ternary diagrams shows that the studied clays may be used in the production of red-stoneware products in ceramic industry. This analysis of clay minerals was made to evaluate the industrial use of clay horizons they belong to and understand their multi-dimensional role in coal-bearing process.

Key words: Paleobotany, intermontane basin, TG/DTG/DTA, XRD, FT-IR.
\end{abstract}

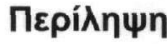

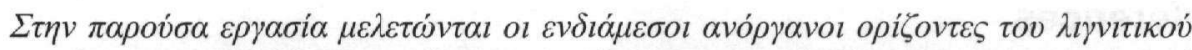

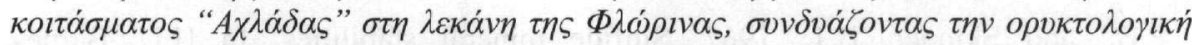

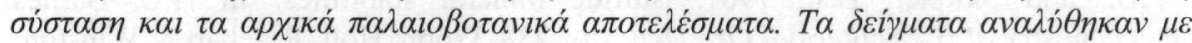

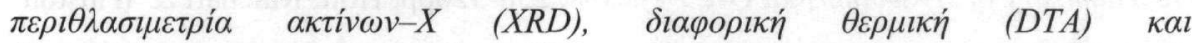

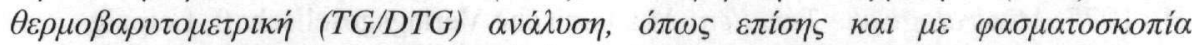

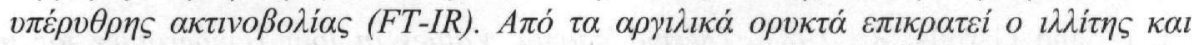

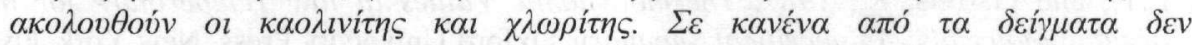

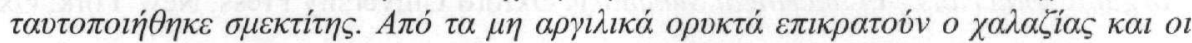

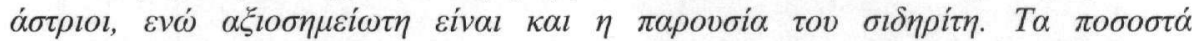

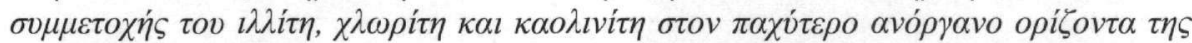

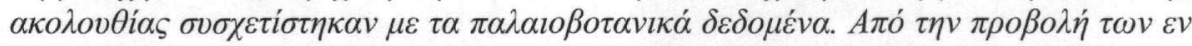

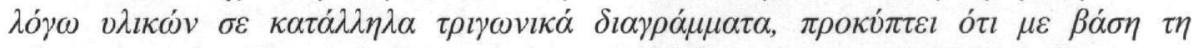

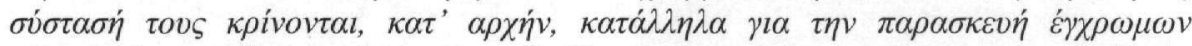

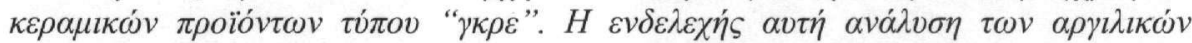

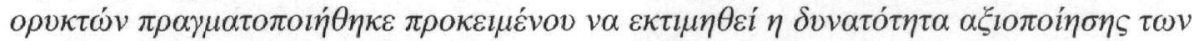

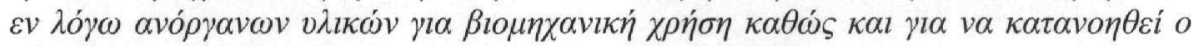

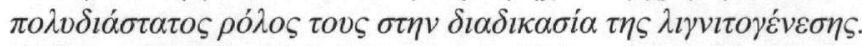

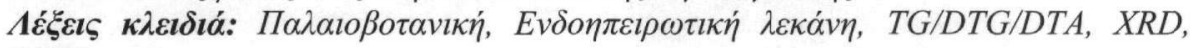
FTIR. 


\section{Introduction}

Significant lignitiferous basins are widespread in Greek peninsula, some of which belong to littoral basins while others to intermontane ones. These lignite deposits are of great interest because of their abundance and of their economic value, as they provide the main amount of raw material needed for electricity production (Georgakopoulos et al. 2000, Papanicolaou et al. 2000, etc)

The individual lignite deposits of Achlada have not been studied by many researchers yet. Kalaitzidis et al. (2003), concluded in the presence of leonardite in Achlada's coal seams, while Antoniadis et al. (2001), focused on the coal-petrography, as well as on seeds and fruits analysis of the intercalated inorganic horizons. Moreover, Zeppos et al. (1993), researched the total lignite deposits that are present at Florina's subbasin east margins.

The aim of the present study is to examine the mineralogical composition of the inorganic intercalated horizons of Achlada lignitiferous succession, in order to evaluate their possible industrial uses as well as to comprehend their correlation with the paleoecological system they were developed.

\section{Geological Settings}

Achlada region is a part of a broader Neogene basin in NW Macedonia (Greece) (Fig. 1). The latter, extends from Monastiri (F.Y.R.O.M), in a NNW - SSE direction, up to the hills of Kozani through the cities of Florina, Amynteon and Ptolemais. The basin is almost $100 \mathrm{Km}$ long and $15-$ $20 \mathrm{Km}$ wide (Pavlides 1985). More specifically the studied area is located at the East margins of the Florina basin.

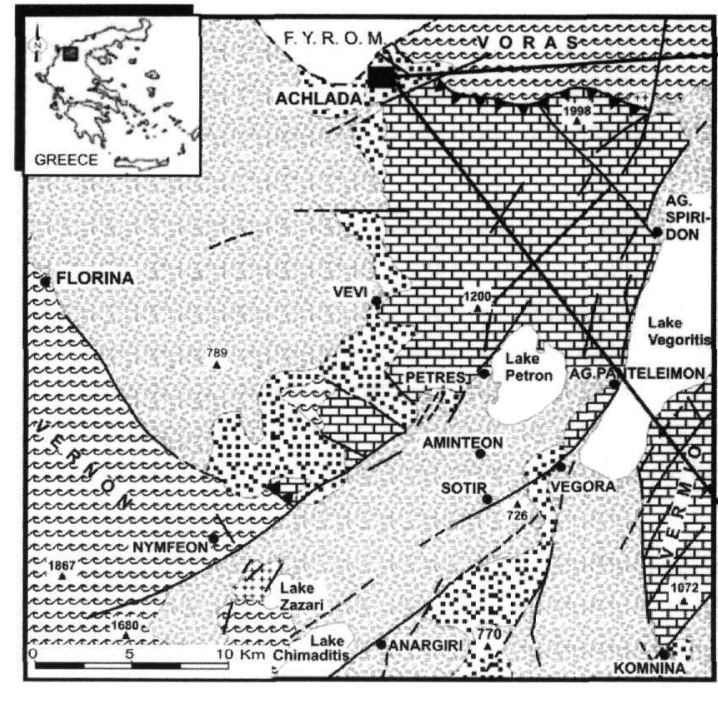

LEGEND

19.23: Undivided Quaternary

:- Undivided Neogene

项 Mesozoic carbonate cover

+++ Upper Carboniferous granite

wece Lower Palaeozoic metamorphic rocks

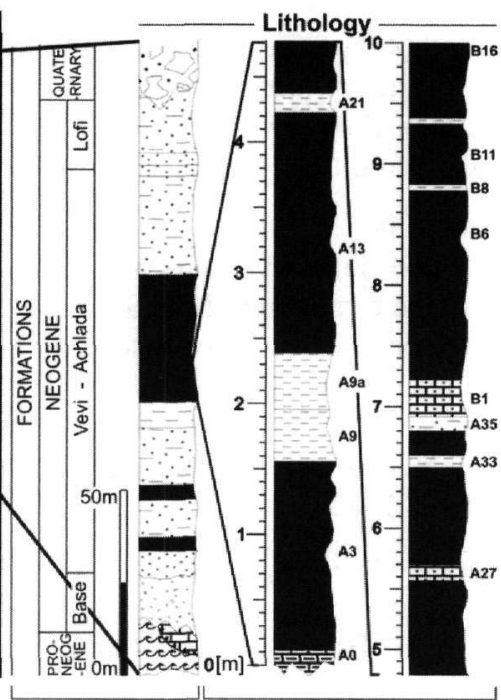

(a)

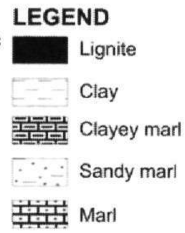

(b)

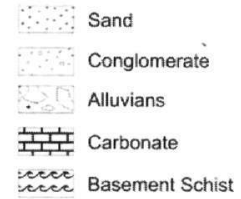

Figure 1 - Geological map of the Florina basin with the location and the generalized lithological column (a) of the studied area (after Pavlides and Mountrakis 1987). (b) lithological column of Achlada lignite deposits 
This particular basin belongs to the Pelagonian zone and it consists of Palaeozonic and proPalaezonic crystal schists, the Mesozoic carbonate cover and ophiolites. Moreover, the sediments which fill the basin contain the lignite steams on the top of which fluviotorential or terrestrial deposits are present. The age of the particular sediments is Upper Miocene - Pliocene (Anastopoulos and Koukouzas 1972).

The $\mathbf{1}^{\text {st }}$ Neogene horizon (Base formation,) known as the conglomerate Base (Pavlidis et al. 1987), begins the succession of sediments which constitute the basin. The $2^{\text {nd }}$ Mid - horizon (Vevi - Achlada formation), which appears at the Vevi Achlada coal mines, follows upwards the Base formation and presents alternations of clayey, sandy, marlaic and coal beds. The seams, in which are included the lignite deposits, have a mid thickness of about $35 \mathrm{~m}$ while, as the drill evidence reveal, the specific succession is getting subsidised to the West (Maratos

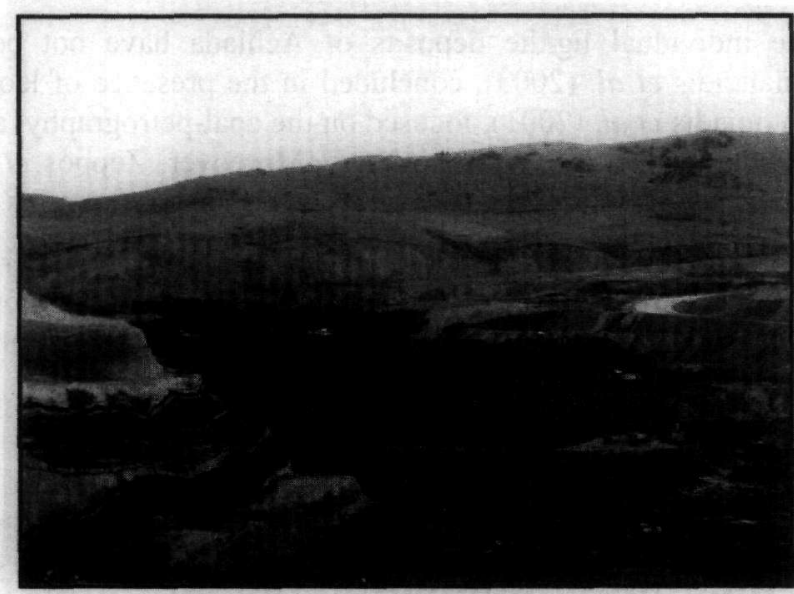

Figure 2 - General view of Achlada lignite deposits with the studied section A-B 1968). The $3^{\text {rd }}$ Upper horizon (Lofi formation) continues the succession with alternations of clays, marlaic breccias, sandy conglomerates and lime marl beds. On the top of this sandy-clay horizon, a marly limestone bed is getting formed, which covers the entire basin. Finally, limnodeltaic, fluviotorential and terrestrial Quaternary sediments of small thickness complete the lithological coloumn.

Concerning the tectonic activity of the study area, two main fault directions are dominant. A NESW direction and a NW-SE one almost vertical to the first. Furthermore, a number of smaller faults, whose direction is NW-SE, have been observed at the Vevi - Achlada recent sediments. A similar tectonic structure is observed at the Achlada coal mine sediments, where the inclinations are about $15^{\circ} \mathrm{SSW}$. Additionally, NW-SE big faults subside the Neogen sediments to the SW (Pavlidis et al. 1987). Finally, the presence of Achlada - Scopos-Papadia big fault, with a NE-SW direction, is very important due to the fact that it's a result of a pro-neogene neotectonic activity (Mountrakis 1983).

In figure 2 is depicted a general view of Achlada lignite deposits with the studied section A-B.

\section{Materials and Methods}

Fourteen (14) samples, of which the stratigraphical location is marked in Figure 1, were analyzed for mineralogical and paleobotanical purposes. The sample collection took place in the direction as shown in Figure 2, successively and in little distance each other, providing us a detailed representation of the lignitiferous sequence. The preparation of each of these samples was defined by the analysis that was about to take place. In detail, all kind of analyses we used and their corresponding preparation is presented below.

The mineralogical composition of the collected samples was determined by means of X-ray diffraction (XRD), thermo-gravimetric (TG/DTG) and differential thermal analysis (DTA) and Fourier Transform (FT-IR) spectroscopy. 
X-ray power diffraction patterns were obtained using a Siemens D-5000 diffractometer, with Nifiltered $\mathrm{CuKa}_{1}$ radiation $(\lambda=1.5405 \AA$ ), operating at $40 \mathrm{kV}, 30 \mathrm{~mA}$. For X-ray Diffraction (XRD) analysis, samples were prepared as unorientated and orientated mounts. The last ones, which consist of $<53 \mu \mathrm{m}$ material, were firstly separated by centrifuging and then placed on a glass slide as a thin layer and allowed to dry at room temperature. Clay fractions were analyzed after glycolation and heating to 450,500 and $550{ }^{\circ} \mathrm{C}$, in order to identify the various clay minerals phases.

The chemical analyses were carried out by Inductively Coupled Plasma-Mass Spectrometry (ICP-MS; at the Cologne laboratory). For ICP-MS, microwave high pressure/temperature decomposition of samples $\left(230^{\circ} \mathrm{C}, 7.0 \mathrm{MPa}\right.$; Paar Physica Multiwave sample preparation system) was carried out using in all stages Merck Suprapurs grade reagents $\left(\mathrm{HF}, \mathrm{HClO}_{4}, \mathrm{HNO}_{3}\right.$, and $\left.\mathrm{HCl}\right)$. Measurements were made on a Sciex/Perkin-Elmer ELAN 6000 ICP-MS (quadrupole mass spectrometer).

The IR measurements were carried out using a Fourier Transform IR (FT-IR) spectrophotometer (Perkin Elmer 880). The FT-IR spectra, in the wavenumber range from $400 \mathrm{~cm}^{-1}$ to $4000 \mathrm{~cm}^{-1}$, were obtained using the $\mathrm{KBr}$ pellet technique. The pellets were prepared by pressing a mixture of the sample and of dried $\mathrm{KBr}$ (sample: $\mathrm{KBr}$ approximately 1:200), at 8 tons $/ \mathrm{cm}^{2}$.

Differential thermal analysis (DTA) and thermo-gravimetric (TG/DTG) analysis were obtained simultaneously using a Mettler Toledo 851 instrument. The samples were heated from $20{ }^{0} \mathrm{C}$ to $1200{ }^{\circ} \mathrm{C}$ at a constant rate of $10{ }^{\circ} \mathrm{C} / \mathrm{min}$.

Furthermore, for coal-petrographic analysis, polished blocks $(\varnothing 3 \mathrm{~cm})$ were prepared according to the national standards [American Society for Testing and Materials (ASTM) D 2797 (1990)]. Then the samples were studied using the Orthoplan Leitz 307 coal-petrographic microscope (objective magnification 50X, oil immersion, monochromatic light at $546 \mathrm{~nm}$ ).

Finally, the samples for paleobotanic analysis were prepared according to Kaiser et al. (1974), while the investigation was carried out using an Orthoplan Leitz 307 metallographic microscope and a Wild M 8 stereoscope.

\section{Results and Discussion}

\subsection{Mineralogy}

\subsubsection{X-ray diffraction (XRD) analysis}

The clay minerals prevail in all the samples, with illite being the dominant phase, kaolinite and chlorite to be the next (Fig. 3). No smectite was found. The non clay minerals are mainly quartz and feldspars. The presence of siderite, in the majority of the samples, is also remarkable.

Quartz is identified by its typical peaks (101) at $\mathrm{d}=3.34 \AA$ and (100) at $\mathrm{d}=4.26 \AA$, while feldspars are identified by the peaks $(002)$ at $\mathrm{d}=\sim 3.19 \AA$ and $(220)$ at $\mathrm{d}=\sim 3.24 \AA$. In addition, illitemuscovite is identified by the sharp diffraction peak (001) at $\mathrm{d}=\sim 10 \AA$ and $(003)$ at $\mathrm{d}=\sim 3.34 \AA$. Kaolinite is identified by its typical peaks $(001)$ and $(002)$ at $\sim 7.1 \AA$ and $d=\sim 3.5 \AA$, while chlorite by the peaks (001) and (002) at $\mathrm{d}=\sim 14 \AA$ and $\mathrm{d}=\sim 7 \AA$, respectively.

In a representative orientated sample (Fig. 3) is shown a combined kaolinite and chlorite peak, which is also present in glycolated sample (Fig. 5). In order to identify these two minerals (kaolinite and chlorite), the thermal behavior of the samples was examined (Fig. 4). 


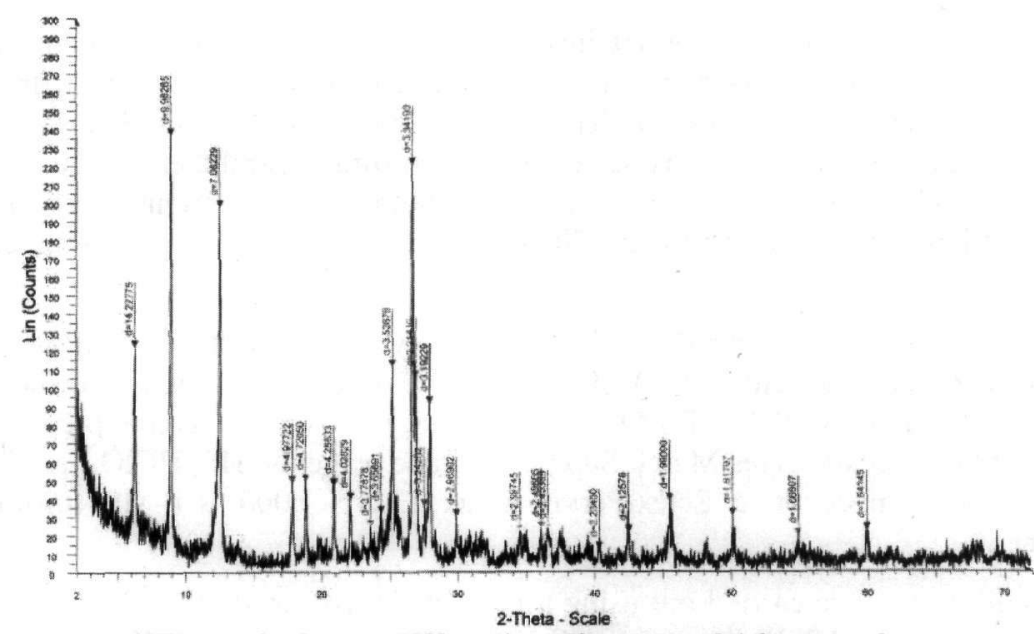

Figure 3 - X ray diffraction diagram of A9a sample

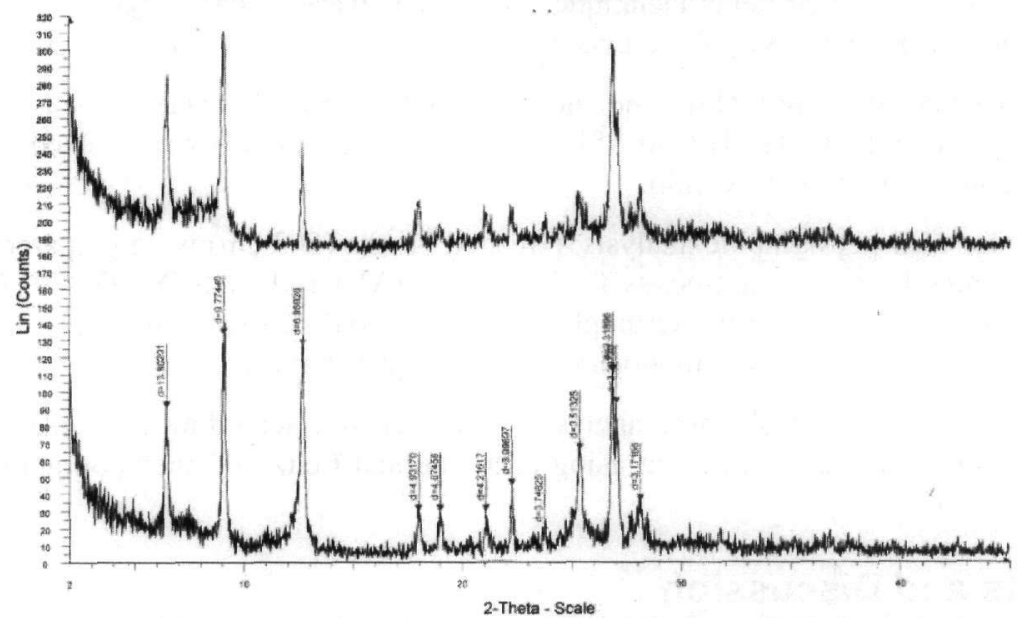

Figure 4 - X ray diffraction diagrams of $\mathrm{A9}$ 9 sample, before an after heating up to $550{ }^{\circ} \mathrm{C}$

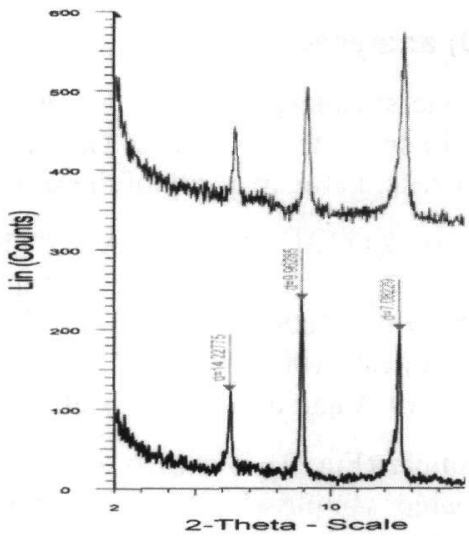

Figure 5 - X-ray diffraction diagram of sample A9a after its saturation with glycol 
The samples were heated up to $550^{\circ} \mathrm{C}$ for 2 hours, in a static oven. Samples were then cooled at room temperature and examined by x-ray power diffraction. A decrease in the intensity of the characteristic diffraction patterns at $\mathrm{d}=\sim 7.07 \AA$ and $\mathrm{d}=\sim 3.52 \AA$, due to the collapse of kaolinite as shown in figure 4 , indicates clearly the presence of kaolinite. No smectite was found in the studied samples, as its typical peak $(100)$ is not shifted from $d=\sim 14 \AA$ to lower $2 \theta(d=\sim 17 \AA)$ after saturation with ethylene glycol (Fig. 5).

The X-ray diagrams of different samples of the A0 horizon (Fig. 8) show that illite-muscovite contribution is higher than that of the A9 and A9a horizons. Therefore, illite-muscovite is the dominant mineral in the A0 horizon, while kaolinite, chlorite and feldspars contribute in minor amounts. In this individual horizon, it is very characteristic that muscovite crystals are observed macroscopically. For A13 horizon, in particular, it is crucial to mention the presence of siderite $\left(\mathrm{FeCO}_{3}\right)$ and the minor contribution of phyllo-silicates minerals, as well.

Upwards (stratigrafically), the characteristics of A21 horizon are similar to those of A9 and A9a, while at both A27 and A33 horizons is observed the increase of illite-muscovite and the decrease of kaolinite and chlorite. Furthermore, at these seams the contribution of quartz, feldspars and siderite is minor. The A35 horizon in comparison to those of A27 and A33, presents, on one hand a decrease of kaolinite and chlorite contribution and on the other hand an increase of illitemuscovite and feldspars. The presence of siderite is obvious, while the quartz contribution is minor. Concerning the horizon B1, kaolinite and chlorite are present. Quartz contribution is minor while there is no indication for the presence of feldspars. At the B8 horizon is observed a vivid presence of illite-muscovite with parallel decrease of kaolinite, while the absence of chlorite is typical. Finally, the examination of the B11 and B16 horizons indicates that illite-muscovite is the dominant clay mineral and kaolinite to be the next.

\subsubsection{Fourier Transform Infrared Specrtoscopy (FT-IR)}

From the derived FT-IR spectra of representative sample (Fig. 6) from Achlada's lignitiferous sequence, we inferred the following results:

- The bands at around $649,534 \mathrm{~cm}^{-1}$ originate from $\mathrm{Si}-\mathrm{O}-\mathrm{Al}{ }^{\mathrm{VI}}$ vibrations (Al in octahedral coordination), while the band at around $468 \mathrm{~cm}^{-1}$ is attributed to the Si-O-Si bending vibrations (van Jaarsveld et al. 2002, Madejova 2002)

- The $1032 \mathrm{~cm}^{-1}$ and $1013 \mathrm{~cm}^{-1}$ band arise from the $\mathrm{Si}-\mathrm{O}-\mathrm{Si}$ and $\mathrm{Si}-\mathrm{O}-\mathrm{Al}^{\mathrm{VI}}$ vibrations, respectively.

- The $1104 \mathrm{~cm}^{-1}$ band is attributed to the stretching vibration of $\mathrm{Si}-\mathrm{O}_{\text {apical }}$.

- Bands at $937 \mathrm{~cm}^{-1}$ and $915 \mathrm{~cm}^{-1}$ arise from the vibrations of outer and inner $\mathrm{OH}$ groups, respectively (Al-OH-Al), while the $792 \mathrm{~cm}^{-1}$ and $755 \mathrm{~cm}^{-1}$ band occur because of the OH translational vibrations (Madejova 2002, Deng et al. 2002).

- The $3699 \mathrm{~cm}^{-1}$ strong band arises from the in-phase symmetric stretching vibration of the $\mathrm{OH}$ groups, either outer or inner surface $\mathrm{OH}$ of the octahedral sheets, which form weak hydrogen bonds with the oxygens of the next tetrahedral layer (Balan et al. 2001). On the other hand, the $3618 \mathrm{~cm}^{-1}$ strong band is due to the stretching vibrations of the "inner $\mathrm{OH}$ groups", lying between the tetrahedral and the octahedral sheets (Madejova 2002).

- The broad band, near $3428 \mathrm{~cm}^{-1}$, is due to $\mathrm{H}-\mathrm{O}-\mathrm{H}$ vibration of absorbed water.

- The band at $1629 \mathrm{~cm}^{-1}$, is due to $\mathrm{OH}$ bending vibrations of adsorbed water.

- The band at $\sim 1405 \mathrm{~cm}^{-1}$ is attributed to siderite, while the one at $\sim 780 \mathrm{~cm}^{-1}$ to quartz.

From all the above mentioned results it becomes clear that the FT-IR spectra confirm the presence of illite, kaolinite and chlorite in all the studied samples. 


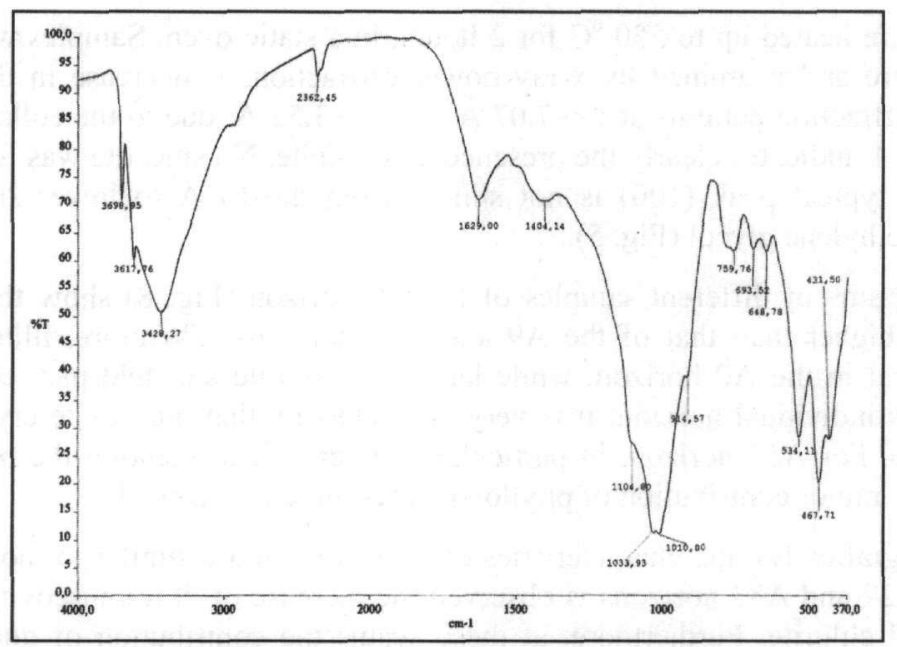

Figure 6 - FT-IR spectra of A9a sample

\subsubsection{TG/DTG and DTA analysis}

The results of the thermal study of the samples examined after heating up to $1200{ }^{\circ} \mathrm{C}$, at a rate of $10^{\circ} \mathrm{C} / \mathrm{min}$ confirm the presence of illite-muscovite kaolinite, and chlorite, as well as siderite.

From the TG and DTA curves of a representative sample (Fig. 7), we conclude that:

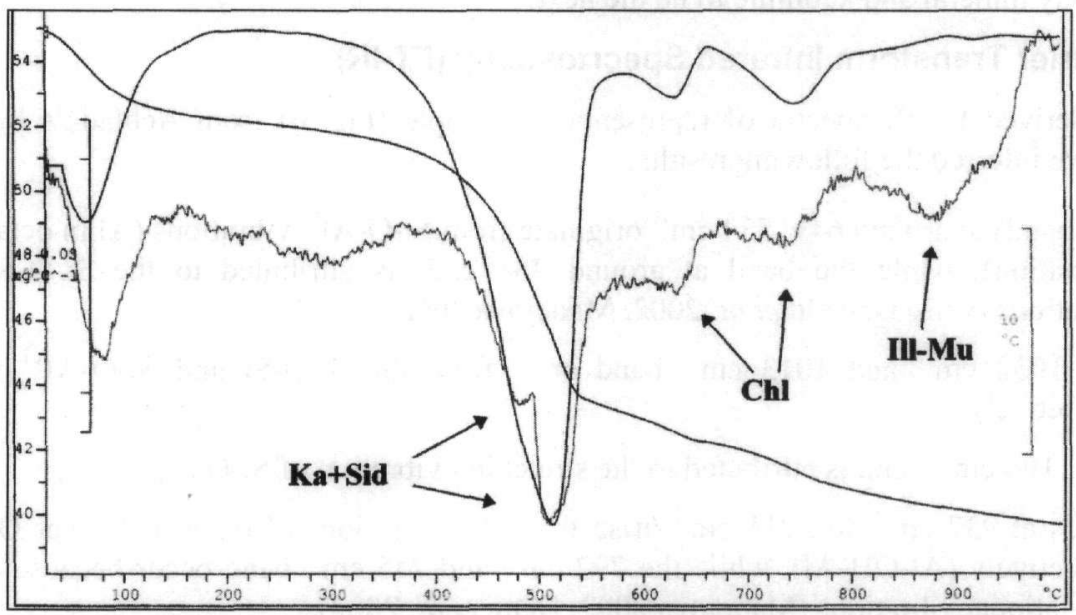

Figure 7 - DTA of A13 (1A) sample. Ka=Kaolinite, Sid=Siderite, Chl=Chlorite and Ill-Mu=Illite-Muscovite

- In the temperature range from $25{ }^{\circ} \mathrm{C}$ to $100{ }^{\circ} \mathrm{C}$, the weight loss due to hygroscopic water is $3.611 \%$.

- In the temperature range from $400{ }^{0} \mathrm{C}$ to $650{ }^{0} \mathrm{C}$, the rapid weight loss (13.305) is documented by the steep slope of the TG curve and a characteristic endothermic peak at $\sim 550{ }^{\circ} \mathrm{C}$ on the DTA curve. This is attributed to the dehydroxylation of the kaolinite, (due to the loss of $\mathrm{OH}$ groups, surrounding the $\mathrm{Al}^{\mathrm{VI}}$ atoms) and the progressive transformation from the octahedral co-ordinated $\mathrm{Al}$, in kaolinite, to a tetrahedral co-ordinated form, in metakaolinite, through the breaking of $\mathrm{OH}$ bonds (van Jaarsveld et al. 2002). Considering the presence of siderite, a part of the weight loss in this temperature range comes from the 
decomposition of siderite according to the reaction $\mathrm{FeCO}_{3} \rightarrow \mathrm{FeO}+\mathrm{CO}_{2}$. Chlorite and illitemuscovite give endothermic peaks at higher temperatures

- On the other hand, as the temperature rises, amorphous or strongly disordered states can be found between the subsequent crystalline phases, while they are transformed at higher temperatures. These transformations can be recognized from exothermic effects at about $980{ }^{0} \mathrm{C}$.

\subsection{Paleobotany}

On the basis of the fact that the mineralogical analysis was carried out on the intercalated inorganic seams of the lignite-bearing sequence, an initial approach concerning the percentage of inorganic material inside the organic horizons of the succession was mandatory. The latter was succeeded by micropetrographic analysis of which results are plotted in Figure 8 .

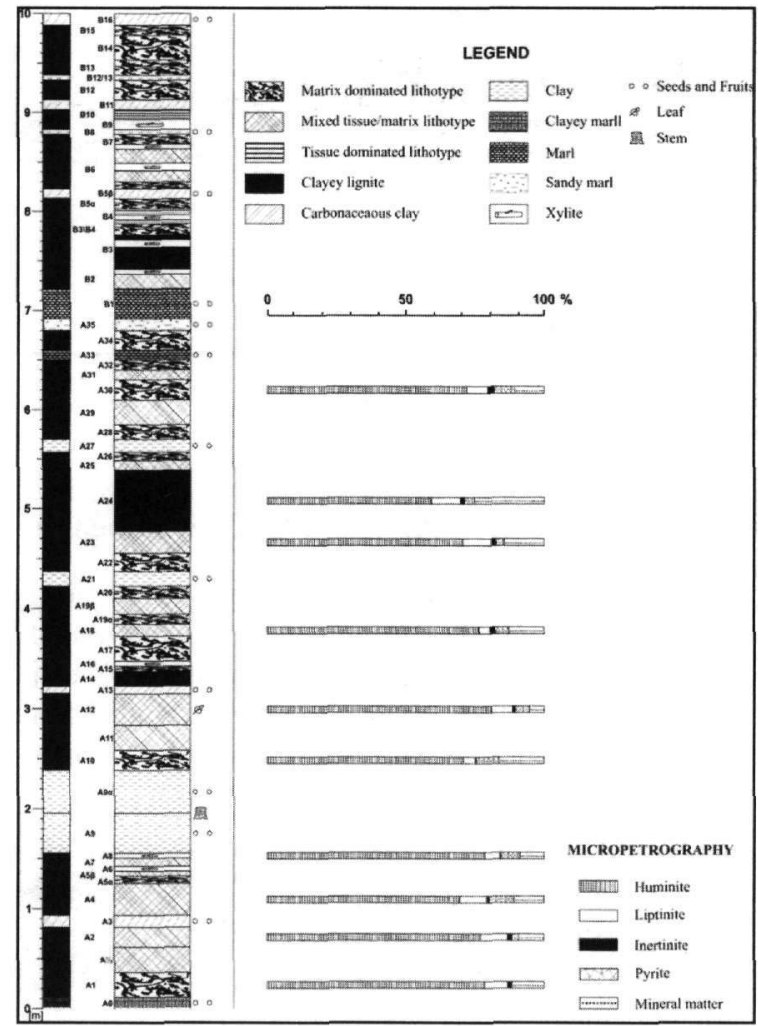

Figure 8 - Micro- and macropetrographical analysis of coal seams in studied area

On the left side of this figure the lithology of the sequence is depicted. In the center is shown the macropetrogaphic description of lignite lithotypes and their succession in the seam as well, based on a modified version of the classification and descriptive scheme used by Vogt (1980) in the study of other lignite deposits (Kaouras 1989). The individual characteristics of Greek lignites, such as the high content in clay minerals, were also considered. Moreover, on the right the percentages of the three main maceral groups are presented (huminite, inertinite and liptinite) and so are these of the mineral matter. From the same diagram it becomes clear that not only is the huminite the dominant maceral group but there is a high content in mineral matter in all the samples, as well.

The next stage of this particular research will be the systematic analysis of mineral mater incorporated inside the organic seams. This kind of analysis will provide evidence about the 
distribution of mineral mater inside the organic beds as well as the way it is correlated to that of intercalated inorganic horizons of the lignite sequence.

In order to combine the paleoenvironment of this individual lignite deposit with the distribution of mineral phases, which were determined in the intercalated inorganic seams, a number of palynological and carpological analyses, were accomplished. The palynological results indicated the presence of Pinaceae, Polypodiaceae, Taxodiaceae, Ulmus, Betula, Alnus, Carpinus, Myrica, Cyrillaceae, Tilia, Compositae, Acer, Fagus, Magnoliaceae, Palmae, Cyperaceae, Gramineae, Sparganiaceae, Plankton and Ovoidites, while the carpological analyses showed the presence of Symplocos, Sambucus, Rubus, Pterocarya, Meliosma, Actinidia, Glyptostrobus, Epipremnites, Decodon, Sparganium, Batrachium, Potamogeton, Nymphaeaceae, Algin and Epiphytes.

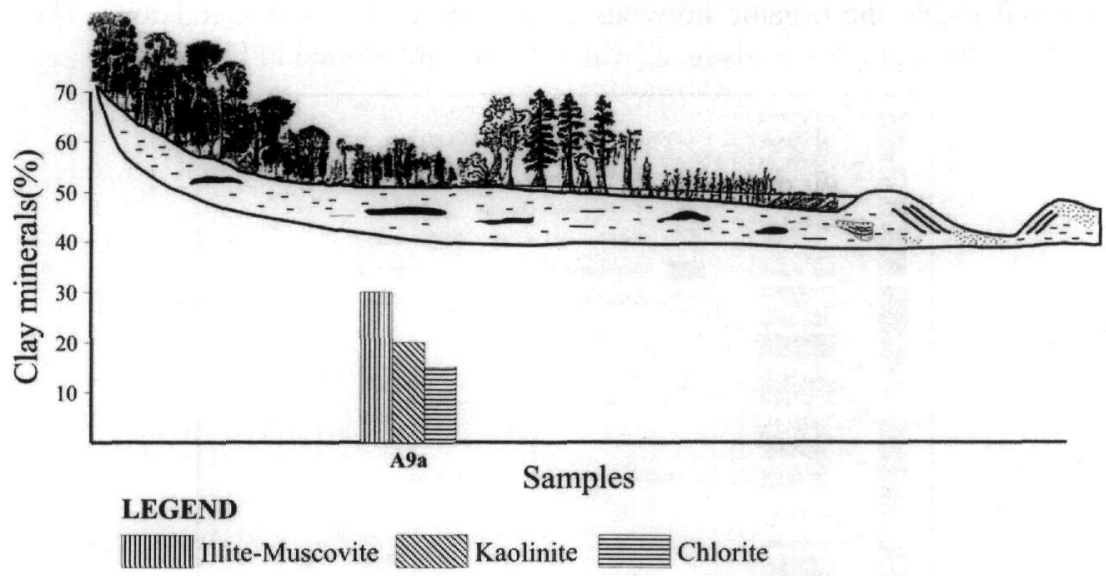

Figure 9 - Distribution of clay minerals in the paleoenvironment of the studied area

The results of these two different kinds of analyses, not only do they verify one another, but also provide the essential information for paleoenvironment representation of the studied area. The correlation of mineralogical and paleobotanical results enables the estimation of the mineral phases' percentage (after semi-quantitative analysis) in each individual paleoenvironment In Figure 9 are depicted the above mentioned initial results, which in advance will be completed and correlated with the mineralogical analysis of the organic horizons.

Taking into consideration the initial paleobotanical results (coal-petrography, palynology and carpology), the sedimentological characteristics and the mineralogical analysis of the intercalated inorganic horizons of the Achlada lignite deposits, it was attempted to approach the palaeoecological reconstruction of the general area (Fig. 10).

This model depicts a main meandering river system, at the right side of which an abandoned channel is present. After meander's cutting-off, clays and peat were deposited onto initial sandy sediments under mainly aquatic conditions in the abandoned

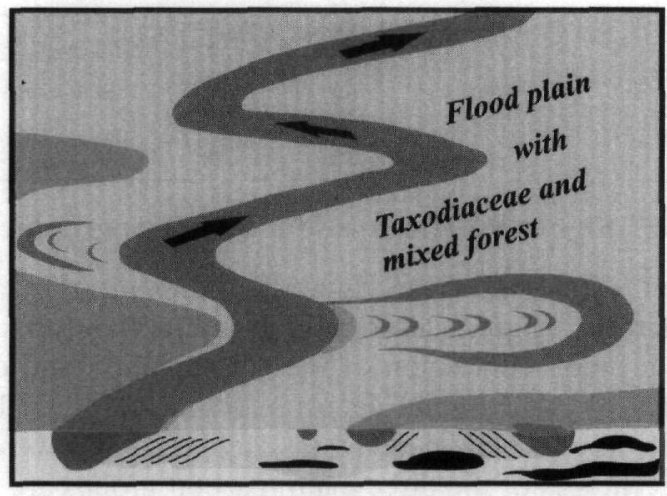

Figure 10 - Paleoecological reconstruction of the general area channel. The studied area, which constituted a flood plain, in combination with the formation of the oxbow lake within the abandoned channel, created a landscape where swamp conditions were dominant and periodical flood episodes together with deposition of fine sediments occurred. 
The flora spices which had grown above the sediments, at the examined area, were determined, as it has already been mentioned, by carpological and palynological analyses and include the presence of Taxodiaceae, Betulaceae, Myricaceae, Tiliaceae ect.

\subsection{Ternary diagrams for traditional products in ceramic industry}

On the basis of the chemical (Table 1) and mineralogical composition of clay raw materials, ternary diagrams have already been constructed for their use in the traditional products of ceramic industry: "red-stoneware", "cottoforte" and "majolica" (Fabbri and Fiori 1985). These are the most suitable to define and visualize compositional fields. The vertices of the above mentioned diagrams have the following compositions:

$$
\begin{aligned}
& \mathrm{SiO}_{2} / \mathrm{Al}_{2} \mathrm{O}_{3}+\mathrm{TiO}_{2} / \mathrm{Fe}_{2} \mathrm{O}_{3}+\mathrm{MgO}+\mathrm{CaO}+\mathrm{K}_{2} \mathrm{O}+\mathrm{Na}_{2} \mathrm{O} \\
& \mathrm{Fe}_{2} \mathrm{O} / \mathrm{MgO}+\mathrm{CaO} / \mathrm{K}_{2} \mathrm{O}+\mathrm{Na}_{2} \mathrm{O}
\end{aligned}
$$

The first diagram, shown in Figure 11a, is the most representative to define the compositional fields as it comprises practically the whole chemical composition of the raw materials. On this diagram, the examined samples fall near the global fields "red-stoneware" and "cottoforte". On the second diagram (Fig 11b), the examined samples have also been plotted, near the same fields.

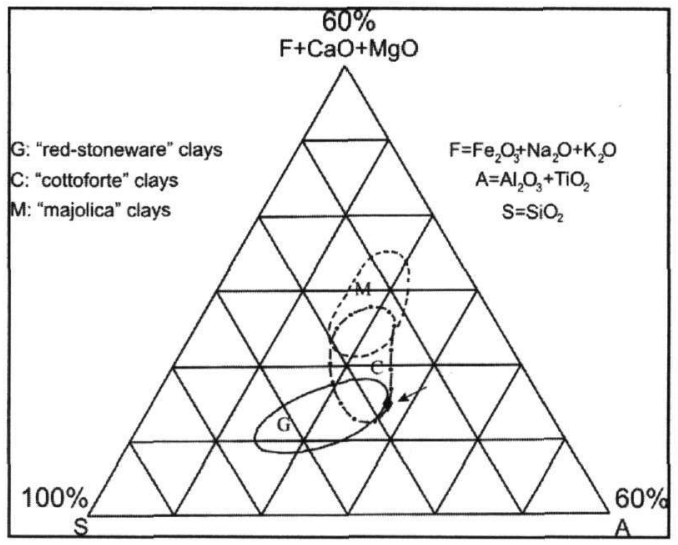

(a)

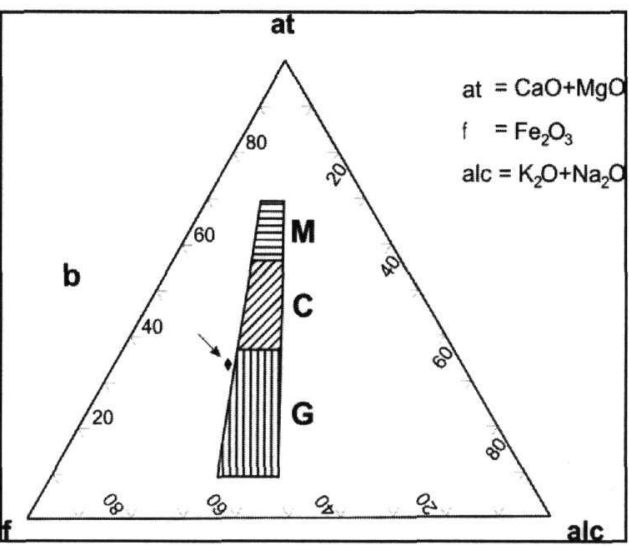

(b)

Figure 11 - (a) Ternary diagram $\mathrm{SiO}_{2} / \mathrm{A1}_{2} \mathrm{O}_{3}+\mathrm{TiO}_{2} / \mathrm{Fe}_{2} \mathrm{O}_{3}+\mathrm{MgO}+\mathrm{CaO}+\mathrm{K}_{2} \mathrm{O}+\mathrm{Na}{ }_{2} \mathrm{O}$, (b) Ternary diagram $\mathrm{Fe}_{2} \mathrm{O} / \mathrm{MgO}+\mathrm{CaO} / \mathrm{K}_{2} \mathrm{O}+\mathrm{Na}_{2} \mathrm{O}$

On the other hand, the mean mineralogical composition of the examined samples was plotted (Fiori and Guarini 1990), in the ternary diagram: "quartz + kaolinite/chlorite + carbonates + iron oxides/illite-muscovite + feldspars" (Fig. 12).

From a mineralogical point of view, these diagrams depict that these clays are suitable for the production of red-stoneware products.

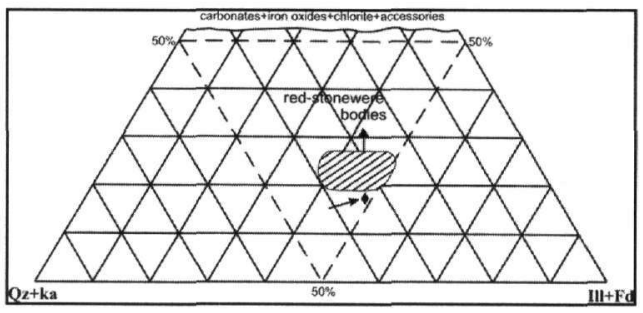

Figure 12 - Ternary diagram for ceramic bodies:

"Quartz+kaolinite/chlorite+carbonates+iron oxides/illite-muscovite+feldspars" 
Table 1 - Chemical composition of the studied samples, ( $\%$ w/w)

\begin{tabular}{|c|c|c|c|c|c|c|c|c|c|c|c|c|}
\hline & $\mathbf{A 0}$ & $\mathbf{A 9}$ & $\mathbf{A 9 a}$ & $\mathbf{A 1 3}$ & $\mathbf{A 2 1}$ & $\mathbf{A 2 7}$ & $\mathbf{A 3 3}$ & $\mathbf{A 3 5}$ & $\mathbf{B 1}$ & $\mathbf{B 8}$ & $\mathbf{B 1 1}$ & $\mathbf{B 1 6}$ \\
\hline $\mathrm{SiO}_{2}$ & 48,0 & 47,0 & 50,1 & 43,7 & 50,5 & 51,7 & 52,5 & 23,7 & 51,6 & 51,5 & 50,6 & 49,3 \\
\hline $\mathrm{Al}_{2} \mathrm{O}_{3}$ & 21,4 & 28,0 & 23,1 & 16,3 & 23,2 & 24,8 & 22,1 & 16,1 & 27,6 & 24,1 & 25,2 & 28,0 \\
\hline $\mathrm{Fe}_{2} \mathrm{O}_{3}$ & 12,9 & 10,0 & 7,5 & 18,2 & 7,3 & 5,5 & 5,7 & 33,0 & 4,8 & 4,2 & 5,2 & 4,6 \\
\hline $\mathrm{MgO}$ & 2,2 & 4,8 & 3,7 & 1,8 & 4,1 & 3,0 & 2,2 & 2,8 & 2,6 & 2,1 & 2,7 & 2,6 \\
\hline $\mathrm{CaO}$ & 2,2 & 3,2 & 2,5 & 2,8 & 1,8 & 1,4 & 1,6 & 4,0 & 1,2 & 1,7 & 1,1 & 2,3 \\
\hline $\mathrm{K}_{2} \mathrm{O}$ & 4,9 & 5,0 & 4,0 & 2,0 & 3,6 & 4,6 & 4,0 & 3,3 & 3,4 & 3,8 & 4,6 & 5,0 \\
\hline L.O.I & 9,36 & 3,0 & 10,1 & 16,2 & 10,34 & 9,9 & 9,8 & 18,2 & 9,8 & 10,6 & 9,7 & 9,2 \\
\hline
\end{tabular}

\section{Conclusions}

The mineralogical study of the inorganic intercalated horizons of "Achlada" lignite deposits showed that the clay minerals prevail in all the samples, with illite-muscovite being the dominant phase, kaolinite and chlorite to be the next. No smectite was found. In addition to clay minerals, the other mineral phases identified are mainly quartz and feldspars. The presence of siderite, in the majority of the samples, is also remarkable. The illite, kaolinite and chlorite percentages of the thicker inorganic horizon were correlated to the paleoenvironmental data. The paleoenvironment of the general area was an active lignite bearing region, which was periodically flooded creating flood plains across general meandering river system. From a mineralogical and chemical point of view, the classification of this particular material into appropriate ternary diagrams shows that the studied in the production of red-stoneware products in ceramic industry.

\section{Acknowledgments}

The authors would like to give special thanks to Dimitrios Tsiakalos for his staunchly support during the laboratorial study. In addition, many thanks are dedicated to $\mathrm{PhD}$ student Nikolaos Toungiannidis and Hon. Prof. Dr. Haino Uwe Kasper for the chemical analyses they accomplished at the University of Cologne as well as to Greek State Scholarships Foundation (S.S.F).

\section{References}

American Society for Testing and Materials (ASTM) D 2797, 1990. Preparing coal samples for microscopical analysis by reflected light. 1990 Annual Book of ASTM Standards, Part 26, Gaseous Fuels: Coal and Coke. ASTM, Philadelphia, PA, 270-273.

Anastopoulos, I., and Koukouzas, K., 1972. Economic geology of the southern part of the Ptolemais Lignite Basin (Macedonia, Greece), Geol. Geophys. Res., 16(1), 1-189. (in Greek)

Antoniadis, P., Vlachou, A., Abatzi, S.M., Khanaga, P., and Riegel, W., 2001. Preliminary coalpetrographic study of the Achlada lignite deposit in the Florina domain, Proc. 9th Int. Congress (Athens, September 2001). Bull. Geol. Soc. Greece, XXXIV (3), 1185-1194. (In Greek)

Balan, E., Marco Saita, A., Mauri, F., and Calas, G., 2001. First-principles modeling of the infrared spectrum of kaolinite, Americal Mineralogist, 86, 1321-1330.

Deng, Y., White, N., and Dixon, J., 2002. Effect of Structual Stress on the Intercalation Rate of Kaolinite, Journal of Colloid and Intrface Science, 250, 379-393.

Fabbri, B. and Fiori, C., 1985. Clays and complementary raw materials for stoneware tiles, Miner. Petrog. Acta, 29-A, 535pp. 
Fiori, C., and Guarini, G., 1990. Italian red clays for Stoneware Tile Production: Statistical study of the mineralogical composition, Industrial ceramics, 10 (4), 151-157.

Frost, R., Kristof, J., Horvath, E., and Kloprogge, J., 2000. Vibrational spectroscopy of formamide-intercalated kaolinites, Spectrochimica Acta, 56, 1191-1204.

Georgakopoulos, A., and Valceva, S., 2000. Petrographic characteristics of Neogene lignites from the Ptolemais and Servia basins, Northern Greece, Energy Sources, 22, 587-602.

Kaiser, H., and Ashraf, R., 1974. Gewinnung und Präparation fossiler Sporen und Pollen sowie anderer Palynomorphae unter besonderer Betonung der Siebmethode, Geol. Jb., A 25, 85114, Hannover.

Kalaitzidis, S., Papazisimou, S., Giannouli, A., Bouzinos, A., and Christanis, K., 2003. Preliminary comparative analyses of two Greek leonardites, Fuel, 82, 859-861.

Kaouras, G., 1989. Kohlepetrographische, palynologische und sedimentologische Untersuchungen der pliozänen Braunkohle von Kariochori bei Ptolemais/NW-Griechenland. PhD thesis, Univ. Göttingen, 220pp.

Madejova, J., 2002. FTIR techniques in clay mineral srudies, Vibrational Spectroscopy, 944, 1-10.

Maratos, G., 1968. Florina lignitiferous basin, I.G.E.Y, 41. (in Greek).

Mountrakis, D., 1983. Structural geology of the North Pelagonian zone s.1. and geotectonic evolution of the internal Hellenides, Unpublished Habilitation, University of Thessaloniki, Greece, 283pp. (in Greek).

Papanicolaou, C., Dehmer, J., and Fowler, M., 2000. Petrological and organic geochemical characteristics of coal samples from Florina, Lava, Moschopotamos and Kalavryta coal fields, Greece. Int. J. Coal Geol., 44, 267- 292.

Pavlides, S., 1985. Neotectonic evolution of the Florina - Vegoritis - Ptolemais basin (W. Macedonia, Greece), $P h D$ thesis, Aristotle University of Thessaloniki, 265pp. (in Greek with Engl. abs)

Pavlides, S., and Mountrakis, D., 1987. Extensional tectonics of north-western Macedonia, Greece, since the late Miocene, J. Struct. Geol., 9, 385-392.

Van Jaarsveld, J., Deventer van, J., and Lukey, G., 2002. The effect of composition and termperature on the properties of fly ash- and kaolinite-based geopolymers, Chemical Engineering Journal, 89, 63-73.

Vogt, W., 1980. Makropetrographischer Flözaufbauder rheinischen Braunkohle und Brikettiereigenschaften der Lithotypen, Fortsch. Geol. Rheinland u. Westf., 29, Krefeld.

Zeppos, I., Tsouflidou, S., and Liakoura, K., 1993. Preliminary report for the exploitation of lignite (xylitic) deposits at Florina's subbasin east margins. Public Power Corporation A.A.EA.A.O. Athens. (in Greek) 